Arab World English Journal (AWEJ) Volume 12. Number4 December 2021 Pp.

$132-141$

DOI: https://dx.doi.org/10.24093/awej/vol12no4.9

\title{
Augmented Reality Mobile Application for Children with Autism : Stakeholders' Acceptance and Thoughts
}

\author{
Haida Umiera Hashim \\ English and Linguistics Department, Academy of Language Studies \\ Universiti Teknologi Mara, Shah Alam, Selangor, Malaysia
}

\section{Melor Md Yunus}

Faculty of Education, Universiti Kebangsaan Malaysia, Bangi, Malaysia

Corresponding author : melor@ukm.edu.my

\section{Helmi Norman}

Faculty of Education, Universiti Kebangsaan Malaysia, Bangi, Malaysia

\author{
Received: 8/27/2021 \\ Accepted: 10/4/2021 \\ Published:12/15/2021
}

\section{Abstract}

American Psychiatric Association defined autism spectrum disorder as a neurological disorder due to which a diagnosed child may face difficulty in social communication or have a repeated or restricted set of behaviors. Learners with autism are primarily visual strategy learners, and they tend to learn better through pictures and images. Due to their cognitive disabilities, most learners with autism struggle to acquire new vocabulary. There have been many inventions invented by researchers all over the world to help autistic children with their education; however, not much emphasis put on the interventions that can assist autistic children with their English vocabulary learning process. Hence, this study intends to investigate the stakeholders' acceptance and thoughts on the use of augmented reality mobile applications for children with autism. This study is a qualitative research study where interviews are used as an instrument to gather stakeholders' views on the usefulness of the designed and developed augmented reality technology mobile application. This study involved seven respondents who come from different backgrounds and in different field areas. The results have gathered that the designed and developed mobile application has the prospect of helping children with autism with their English language learning process. With further improvements, the designed and developed mobile application is believed to be able to help autistic children to learn English vocabulary in a more exciting yet meaningful manner and at the same time help to spark their interest in their English vocabulary language learning process.

Keywords : autism spectrum disorder, augmented reality, English as Secondary Language learning, English vocabulary, mobile learning, mobile application

Cite as: Hashim, H. U., Md Yunus, M., \& Norman, H. (2021). Augmented Reality Mobile Application for Children with Autism : Stakeholders' Acceptance and Thoughts. Arab World English Journal, 12 (4)

DOI: https://dx.doi.org/10.24093/awej/vol12no4.9 


\section{Introduction}

Authors like Travis and Geiger (2010) and Hashim et al. (2010) mentioned that there is an increasing number of children across the globe being diagnosed with Autism Spectrum Disorder (ASD). These children are given a spotlight in today's world, especially in the world of education (Castellon, 2021). ASD is defined as a neurological disorder that causes a child with ASD to experience persistent problems in social communication and interactions across multiple contexts (Perrotta, 2019). Children with ASD usually have the same traits in them which they usually show restricted, repetitive patterns of behaviors and interest (Yunus, Bissett, Penkala, Kadar \& Liu, 2019). In today's world of education, inclusive education has been emphasized in making sure children with disabilities have the same opportunities and chances in gaining the best education. It is believed that every learner deserves the same treatment in education. Many developed countries around the globe have ensured and highlighted inclusive education in their education policy (Amor, et al., 2019). It is believed that every learner has the right to education. The same goes for children with autism; they have the same legal right to an education. However, because of their autistic, children with autism usually struggle to succeed in school and also socially (Nuske, et al., 2019).

Autism Spectrum Disorder (ASD) is a neurodevelopment disorder that affects the crucial area of development which are language and communication, social skills, and behaviour, also interest (Senouci, Obeidat \& Ghaouti, 2021). Autism Spectrum Disorder prevalence rate has significantly increased globally (Tiley \& Kyriakopoulos, 2021; Satari, Yasin, Toran \& Mohamed, 2020) and the disorder is no longer a stranger. Many parents of autistic children in today's world are starting to get themselves exposed to the knowledge on how to attend to their autistic children. With the increase of prevalence rate, children with Autism Spectrum Disorder have also been getting attention today by researchers all over in the world who have been conducting researches and interventions that could help autistic children with their language learning. Children with autism usually exhibit difficulty in processing sensory information, which consequently affects their learning, especially language learning (Mahayuddin \& Mamat, 2019). Despite their disabilities, children with autism also have the right to be included in all areas, including learning English language. With the advancement of technology and the world of the 4th Industrial Revolution, English language has become a global language and inclusive education will be helpful for children with autism to survive in the future. Learning a language is a journey and the journey starts with mastering the vocabulary. Susanto (2017) believed that word knowledge or vocabulary is the foundation for most aspects of language and for achievement. Vocabulary learning is to be considered as a very important part of language learning. Literature has shown that several researchers have attempted to look for possibilities and invented strategies to assist autistic children in their language learning. The use of technology as an assistive technology for autistic children for example. Technology as an assistive technology has been making its waves in Autism Education since early 2012 (Park, Bagwell, Bryant \& Bryant, 2021). According to the literature, a number of intervention strategies have been proven successful at helping autistic children with their English vocabulary learning process. Hence, this study intends to investigate stakeholders' acceptance of the usefulness of the designed and developed mobile augmented reality application for English vocabulary learning of children with autism. 


\section{Literature Review}

Children with autism are each to their own. Children with autism globally usually encounter the same issues and challenges due to their condition (Ben at al., 2020). Each one of the autistic children has their preferences and learning styles which can be both an advantage and challenge for them as learners. Learning a language on the other hand, is also a challenging process for children with autism (Maulana \& Bahruni, 2020; Chu, Tang, McConnell, Mohd Rasdi, \& Yuen, 2019). A study of language includes the primary four skills, which are listening, reading, speaking, and writing. One cannot master a language without mastering vocabulary (Salawazo et al., 2020). Especially in English language learning, acquiring vocabulary is a crucial element of the process. The use of English language in today's world has become common and with the language to be considered as a global language (Zuparova, Shegay, \& Orazova, 2020), acquiring the English language is indeed a must have skill. In Malaysia, English language has become the second language and has to be acquired by all students (Kawaguchi, 2021). The language is introduced in the education field as early as at kindergarten level to the tertiary level of education. Be it for typically developed children and autistic children, acquiring English language skills can benefit them in the future with their education and also when they are stepping into the working environment. However, mastering English language will be almost impossible if the learners did not master the vocabulary aspect of the language (Ahsan, Nasir, \& Abbas, 2020).

For autistic children, communication skills are not their forte due to their cognitive disability that makes them usually experience difficulties in their ability to articulate their thoughts verbally (Khairuddin, Salleh, \& Amin, 2020). They typically encounter communication difficulties which is why most of the time, they resort to non-verbal communication, such as shouting, crying and throwing tantrums. Having them learn a new language, especially English language, is indeed a challenge. Dolah and Chal (2020) believe that in helping children with autism to learn vocabulary, interventions using graphic aids that provide concrete, visual symbols can help to benefit them in their vocabulary learning. There have been many strategies and initiatives in helping children with autism to be able to have a smooth sailing language learning journey. One of the initiatives is the use of technology. The use of technology has been making its appearance in autism education since early 2012 Scassellati, Admoni, and Matarić (2012). There have been many technology-based aids invented as an intervention in children with autism's language learning process. Past literature has shown that one of the best ways to engage children with autism with language learning is using technology as an intervention. The advancement of technology, teaching approaches have shifted from traditional teaching to modern education supported by technological equipment (Andrunyk, 2020). Gokaydin et al., (2020) believed that technological developments encourage the production of more informaticsbased tools for children with autism and the possibilities provided by technology today are convenient for the use of children with autism.

Recently, the rise of augmented reality technology may conceivably leave an impactful effect on the world of education and offer better approaches in language teaching and learning (Bakhtiarvand, 2021; Cerdá et al., 2020). Contrasted with other technologies, Bridges, Robinson, Stewart, Kwon and Mutua (2020) believed that augmented reality technology is believed of being not only an effective intervention but also practical for use in natural environments. The easy access to augmented reality for children with autism by using old phones makes augmented 
reality feasible technology. Many past literature has discovered the use of augmented reality technology for children with autism. Berenguer, Baixauli, Gómez, Andrés, and De Stasio (2020) previously has conducted a systematic review on investigating the impact of augmented reality technology on social, cognitive and behavioral domains in children with autism. Their results have gathered that the majority of findings from the literature support the claim that the use of augmented reality can provide meaningful and enjoyable experiences to children with autism. The use of augmented reality have also been said to be able to help children with autism to feel more motivated in their learning and it allows them to understand more information (Kellems, Charlton, Kversøy, \& Györi, 2020). It is believed that technology and innovation currently give more available approaches to produce an efficient hub of rich knowledge for children with autism.

When the literature of technology-based research for children with autism was examined, it can be seen that one of the best technologies that can act as an assistive technology for autistic children is the augmented reality technology. Even though the use and intervention of technology in the world of autism education has evolved since 2012, interventions that involve special education children can be more challenging for researchers. There have been many types of research involving the use of augmented reality technology; however, there has not been much on the use of augmented reality technology for the purpose of ESL learning classrooms.

\section{Methodology}

This study is a qualitative study of nature in which the researchers intend to investigate the acceptance and perceptions of the participants on the designed and developed augmented reality mobile application in detail. Researchers believed that the nature of qualitative study can be helpful in answering the objective of this study.

\section{Participants}

A total of six participants were involved in this study. The participants came from different backgrounds and fields. They are experts in their field with vast experience in the education field.

\section{Instrument}

Semi-structured interview is the instrument employed with seven stakeholders from different backgrounds as the participant. Semi-structured interviews were conducted to gather their acceptance of the designed and developed mobile augmented reality application to help children with autism with their English language learning process.

\section{Procedures}

Interviews were conducted with every participant to gather their acceptance and view on the designed and developed mobile application. A demonstration of the use of the mobile augmented reality application is shown to the respondents. They are needed to evaluate the prototype and then give their thoughts for further improvements. The interview session with the participants varied in terms of duration. It is crucial for researchers to round up each participant's opinions on the mobile application prototype for further improvements. Their perspective and thoughts on a. The design of the mobile application; $b$. The technical aspect of the application 
prototype, c. The contents and; d. The pedagogical elements are taken into consideration. The data from the interviews were then later analyzed and presented.

\section{Findings}

The data from the interviews were then analyzed and the findings are presented in this section. The presentation of this section will start with the findings gathered from the respondents, then later discussed further. The respondents chosen for this study come from different backgrounds and fields. The demographic profile of the respondents is as shown in Table one.

Table 1. The demographic profile of the respondents

\begin{tabular}{|c|c|c|c|}
\hline Respondent & Profession & Expertise & Affiliation \\
\hline Dr. J & Assistant Professor & $\begin{array}{c}\text { Language learning } \\
\text { with technology }\end{array}$ & Shenzhen Technology University, Taiwan \\
\hline Prof. R & Professor & $\begin{array}{c}\text { Mobile Learning \& } \\
\text { English as } \\
\text { Secondary } \\
\text { Language Learning }\end{array}$ & Athabasca University, Canada \\
\hline Dr. RL & Senior Lecturer & $\begin{array}{c}\text { Art \& } \\
\text { Design/Multimedia }\end{array}$ & Universiti Teknologi Mara, Malaysia \\
\hline Prof A. & Professor & Applied Linguistics & Qassim Universiti, Saudi Arabia \\
\hline Ms. S & Teacher & Special Education & A private school, Malaysia \\
\hline Ms. D & Parent & $\begin{array}{c}\text { A parent of Autism } \\
\text { Children }\end{array}$ & Selangor, Malaysia \\
\hline
\end{tabular}

The respondents involved who act as the stakeholders came from different backgrounds. The majority of the respondents are in the education field and are lecturers in technology and mobile learning. There was one respondent who is an English teacher that teaches children with autism and one respondent on behalf of the parents with autistic children. The respondents were to be considered as the stakeholders in this study that could help to play a significant role in providing their thoughts and views on the designed and developed mobile application. All respondents $(100 \%)$ agreed that the design of the mobile augmented reality application is attractive and suitable for the target group. In this study, the end-users of this designed and developed mobile application are children with autism. The respondents thought that the design of the developed mobile application is appealing and could be helpful to attract children with autism in their English vocabulary learning process.

In addition to that, from the element of the technical aspect of the application, all respondents agreed that the designed and developed augmented reality mobile applications are easy to be used and the interface is user-friendly. With regards to the content and pedagogical aspect of the designed and developed a mobile application, all respondents believed that the content designed are aligned with the Special Education syllabus and they believed that the 
application is interesting to be explored as a resource for English vocabulary learning of children with autism. The respondents also provided their views on the strength of the designed and developed mobile augmented reality application and also some recommendations for researchers' acknowledgment in making further improvements. Specifically, the respondents' views are tabulated in Table two below.

\section{Table 2. Respondents' personal views and recommendations}

\begin{tabular}{|c|c|c|}
\hline Respondent & Strengths & Recommendations \\
\hline Dr. J & $\begin{array}{l}\text { "The use of augmented reality technology } \\
\text { can be enticing to young English learners" }\end{array}$ & $\begin{array}{l}\text { "It is necessary to consider the diverse } \\
\text { needs of this specific population, } \\
\text { including their psychological and physical } \\
\text { needs" }\end{array}$ \\
\hline Prof. R & $\begin{array}{l}\text { "It is well designed and easy on the eyes, } \\
\text { while being simple enough for even the } \\
\text { most computer or mobile device illiterate } \\
\text { person to benefit" }\end{array}$ & $\begin{array}{l}\text { "I believe the designed is simple enough } \\
\text { for beginners and can cater to wide range } \\
\text { of learners with different learning styles" }\end{array}$ \\
\hline Dr. RL & $\begin{array}{l}\text { "The strength of these apps lies in the } \\
\text { personality formed from the character } \\
\text { because of the charming and appealing } \\
\text { colours. It conveys a friendly message, and } \\
\text { the way the character communicates } \\
\text { through movement also conveys a } \\
\text { straightforward message that is simple to } \\
\text { understand" }\end{array}$ & $\begin{array}{l}\text { "Audio effects are vital in providing } \\
\text { learning a more meaningful appreciation. } \\
\text { Therefore, audio is required to enhance } \\
\text { the effect of the characters' movement." }\end{array}$ \\
\hline Prof A. & $\begin{array}{l}\text { "It is easy for the target group. With some } \\
\text { more advanced technological touches, } \\
\text { however, it would really be interesting, too" }\end{array}$ & $\begin{array}{l}\text { "Add audio, for pictures alone wouldn't } \\
\text { really serve the purpose. } \\
\text { Keep the pictures or graphics more } \\
\text { attractive" }\end{array}$ \\
\hline Ms. S & $\begin{array}{l}\text { "It can help the children to gain more focus } \\
\text { and to capture their interest throughout the } \\
\text { learning process" }\end{array}$ & $\begin{array}{l}\text { "Use more interesting fonts and add more } \\
\text { inputs which are more useful that can be } \\
\text { used in their daily conversation. Create } \\
\text { games that can help the children to } \\
\text { understand better. Use the themes which } \\
\text { are really exciting to them, like aerospace, } \\
\text { road and highways, dinosaurs and so on, } \\
\text { because autistic children are really } \\
\text { passionate towards such topics" }\end{array}$ \\
\hline Ms. D & $\begin{array}{l}\text { "I think technology integration can help } \\
\text { learners with autism to learn better in the } \\
\text { right context" }\end{array}$ & $\begin{array}{l}\text { "There are also other issues to consider, } \\
\text { light brightness can cause sensory } \\
\text { overload in some. Sensory overload is } \\
\text { another thing to consider with technology } \\
\text { assisted teaching. They could end up } \\
\text { getting distracted rather learning due the } \\
\text { sensory overload. It can be done, it is just } \\
\text { a lot to consider." }\end{array}$ \\
\hline
\end{tabular}




\section{Discussion}

Children with autism typically encounter problems in learning and acquiring vocabulary due to their cognitive disabilities. Although past literature has proven that learners with autism usually tend to grasp English language faster than their mother tongue due to the linguistic aspect of English, children with autism still encounter difficulties in their English language learning process. It is indeed proven that children with autism are different and unique in their own ways. Each one of them has different traits and characteristics that make them different from each other. Due to their uniqueness, each autistic child has different learning styles and preferences.

In their study, Hashim, Yunus, and Norman (2021) have proven that children with autism indeed encounter challenges and issues in their language learning journey. Due to their different behaviors and characteristics, teachers sometimes struggle to try to personalize the learning materials for them. Children with autism learn best via images and augmented reality technology is proven helpful to provide children with autism a meaningful yet fun learning experience. Berenguer et al. (2020) stated that with augmented reality technology, it is easier to provide a platform where virtual and real objects coexist together which allows to improve kinaesthetic and auditory learning for children with autism.

Augmented reality helps children with autism engage and cooperate with the learning materials directly, thus allowing them to connect to the learning process better. Bridges et al. (2020) also agreed that augmented reality technology would help children with autism engage more in their learning process. It is believed that once learners are involved in what they are doing, they tend to be more interested in the learning process. As mentioned by Gokaydin et al. (2020), the utilization of augmented reality technology can help to promote constructivist learning within the children as it gives the children an interactive-based learning condition for dynamic learning. Augmented reality technology will be able to in a way nurture autistic children's autonomous learning and take more responsibility for their learning process.

\section{Implications and Conclusion}

This study is hoped to help children with autism cope with their learning disabilities and help bridge the gap between autistic children and typically developed children in learning. The uniqueness of children with autism is not making their abilities any less than other children. Children with autism will still be able to learn the way typically developed learners learn. It is believed that in helping children with autism to cope with their learning disabilities, one of the ways is by approaching them with materials that are intriguing and can be helpful to them. Augmented reality technology is proven to be one of the most intriguing learning materials as it will help autistic children to connect the virtual and real-life scenarios better (Fatmawaty, Setyaningrum, \& Faridah, 2021).

\section{Conclusion}

The study intends to investigate the stakeholders' acceptance and perceptions towards the use of for English vocabulary learning Augmented reality technology mobile application for children and the findings have gathered that the intervention is indeed able to provide children with autism with a more meaningful learning journey and spark their interest in English vocabulary learning. In addition to that, augmented reality technology applications are also able to contribute to the way children with autism learn daily life skills as well as can facilitate their 
Arab World English Journal (AWEJ) Volume 12. Number 4. December 2021

Augmented Reality Mobile Application for Children with Autism

Hashim, Md Yunus \& Norman

understanding of social communicative behaviour. It is believed that the use of augmented reality technology in autism education is a study that is worth venturing into for future research.

\section{About the Authors:}

Haida Umiera Hashim is a lecturer at the English and Linguistics Department, Academy of Language Studies, Universiti Teknologi Mara, Malaysia. She earned her bachelor's degree and masters degree at the University of Malaya and Universiti Kebangsaan Malaysia (UKM) in the field of education (Teaching English as Secondary Language) respectively. She is currently pursuing her degree of philosophy $(\mathrm{PhD})$ at the Universiti Kebangsaan Malaysia in the same area. ORCid ID : https://orcid.org/0000-0002- 5710-3401

Professor Dr. Melor Md Yunus is a Professor at the Faculty of Education, Universiti Kebangsaan Malaysia and is currently the Deputy Dean (Research and Innovation) at the Faculty of Education, Universiti Kebangsaan Malaysia (UKM). She holds a B.A. in English (Linguistics) from the University of Nevada-Reno, USA and an M.A. in TESL from the Arizona State University, USA. She then earned her Ph.D. in Education (TESL) from the University of Bristol, UK. Her areas of concentration are TESL, language pedagogy and the use of technology in TESL. Her expertise is in the area of Technology-enhanced Language Learning (TELL). ORCid ID : https://orcid.org/0000-0001-7504-7143

Associate Professor Dr. Helmi Norman is currently the Deputy Director of Instructional Technologies of the Center for Teaching and Curriculum Development, Universiti Kebangsaan Malaysia (UKM) and currently drives the e-learning transformation in the university. He is also a senior lecturer at the Faculty of Education, UKM. His research interests are in the field of digital learning and futuristic education. He was awarded as an Apple Distinguished Educator for driving transformation of national projects for primary, secondary, and higher education in promoting 1:1 pedagogical and learning approaches using the Apple ecosystem. He is a certified Professional Technologist of the Malaysian Board of Technologists. Dr Norman's global experience includes his appointment on the board of directors of the International Association for Blended Learning, which pioneers blended learning initiatives around the globe. He is also the pioneer of "dronagogy" in designing futuristic education with drone-based learning. ORCid ID : https://orcid.org/0000-0002-4717-3166

\section{References}

Ahsan, M. U., Nasir, M., \& Abbas, J. (2020). Examining the Causes of Plastic Bags Usages and Public Perception about its Effects on the Natural Environment. International Journal of Academic Research in Business and Social Sciences, 10(10), 80-96. DOI:10.6007/IJARBSS/v10-i10/7919

Amor et al., (2019). International perspectives and trends in research on inclusive education: A systematic review. International Journal of Inclusive Education, 23(12), 1277-1295.

Andrunyk, V. (2020). Visualization of the content of information technologies: supporting the education of students with autism. ECONTECHMOD: An International Quarterly Journal on Economics of Technology and Modelling Processes, 9. 11-18.

Bakhtiarvand, M. (2021). The Impact of Augmented Reality on the Social Skills of Children with High Functioning Autism. Randwick International of Social Science Journal, 2(2), 156-160. 
Arab World English Journal (AWEJ) Volume 12. Number 4. December 2021

Augmented Reality Mobile Application for Children with Autism

Hashim, Md Yunus \& Norman

Bent, S et al., (2020). the experience of parents of children with autism spectrum disorder during the COVID-19 pandemic: A qualitative analysis. Reprints, Version 1. 1-13. Research Square. https://doi.org/10.21203/rs.3.rs-46426/v1

Berenguer, C., Baixauli, I., Gómez, S., Andrés, M. D. E. P., \& De Stasio, S. (2020). Exploring the impact of augmented reality in children and adolescents with autism spectrum disorder: A systematic review. International Journal of Environmental Research and Public Health, 17(17), 6143. https://doi.org/10.3390/ijerph17176143

Bridges, S. A., Robinson, O. P., Stewart, E. W., Kwon, D., \& Mutua, K. (2020). Augmented reality: Teaching daily living skills to adults with intellectual disabilities. Journal of Special Education Technology, 35(1), 3-14.

Castellon, F. A. (2021). Dual Identification: English Proficiency and Educational Placement of English Learners with Autism Spectrum Disorder, (Unpublished Doctoral dissertation). University of California, Los Angeles.

Cerdá, A. G et al., (2020). AUGMENTED REALITY IN INTERVENTION WITH PEOPLE WITH AUTISM SPECTRUM DISORDER: PROTOCOL ACTIVITIES. DOI: 10.36315/2020end047

Chu, S. Y., Tang, K. P., McConnell, G., Mohd Rasdi, H. F., \& Yuen, M. C. (2019). Public perspectives on communication disorders and profession of speech-language pathology. Speech, Language and Hearing, 22(3), 172-182. https://doi.org/10.1080/2050571X.2019.1570705

Dolah, J., \& Chal, A. K. (2020). VISUAL SUPPORT FOR VOCABULARY ACQUISITION IN AUTISM. Turkish Journal of Physiotherapy and Rehabilitation, 32(3), 7200-7207.

Fatmawaty, R., Setyaningrum, R. R., \& Faridah, F. (2021). Vocabulary Materials Based on Picture Media for Autistic Students. Linguistic, English Education and Art (LEEA) Journal, 4(2), 425-435.

Gokaydin, B., et al., (2020). Technology-Supported Models for Individuals with Autism Spectrum Disorder. International Journal of Emerging Technologies in Learning (iJET), 15(23), 74-84. https://doi.org/10.3991/ijet.v15i23.18791

Hashim, H. U., Yunus, M. M., \& Norman, H. (2021). English As Secondary Language Learning and Autism Spectrum Disorder: The Obstacles in Teaching and Learning the Language. Arab World English Journal (AWEJ), 12(2), 22-30. DOI: https://dx.doi.org/10.24093/awej/vol12no2.2

Kawaguchi, S. (2021). Second Language Acquisition and Digital Learning in Asia. Asiatic: IIUM Journal of English Language and Literature, 15(1), 36-52.

Kellems, R. O., Charlton, C., Kversøy, K. S., \& Győri, M. (2020). Exploring the Use of Virtual Characters (Avatars), Live Animation, and Augmented Reality to Teach Social Skills to Individuals with Autism. Multimodal Technologies and Interaction, 4(3), 48.

Khairuddin, K. F., Salleh, S. D., \& Amin, A. S. (2020). Supporting Students with Autism in Tertiary Education: Malaysian Lecturers' Views and Experiences. Universal Journal of Educational Research, 8(11A), 1-8.

Mahayuddin, Z. R., \& Mamat, N. (2019). Implementing augmented reality (AR) on phonicsbased literacy among children with autism. International Journal on Advanced Science, Engineering and Information Technology, 9(6), 2176-2181.

Maulana, R., \& Bahruni, B. (2020). An Android-Based Vocabulary Model for Autism. IJISTECH (International Journal of Information System \& Technology), 3(2), 221-226. 
Nuske, H. J et al., (2019). Broken bridges - new school transitions for students with autism spectrum disorder: A systematic review on difficulties and strategies for success. Autism, 23(2), 306-325. doi: 10.1177/1362361318754529

Park, J., Bagwell, A. F., Bryant, D. P., \& Bryant, B. R. (2021). Integrating Assistive Technology Into a Teacher Preparation Program. Teacher Education and Special Education, 08884064211001447.

Perrotta, G. (2019). Autism Spectrum Disorder (ASD): Definition, Contexts, Neural Correlates and Clinical Strategies. DOI: 10.23880/nnoaj-16000136

Salawazo, I. S et al.,(2020). Analysis of Students' Vocabulary in Learning English. Linguistic, English Education and Art (LEEA) Journal, 3(2), 469-475. https://doi.org/10.31539/leea.v3i2.1017

Satari, N., Yasin, M. H. M., Toran, H., \& Mohamed, S. (2020). Application Reading Module for Children with Disabiliy among Students with Non-Verbal Autism. International Journal of Academic Research in Business and Social Sciences, 10(3). DOI:10.6007/IJARBSS/v10-i3/7083

Scassellati, B., Admoni, H., \& Matarić, M. (2012). Robots for use in autism research. Annual review of biomedical engineering, 14, 275-294. 10.1146/annurev-bioeng-071811-150036

Senouci, M., Obeidat, H., \& Ghaouti, R. (2021). Autism spectrum as a communication disorder: A case study.African Educational Research Journal. Vol. 9(3), pp. 687-695, July 2021 DOI: 10.30918/AERJ.93.21.104

Susanto, A. (2017). The teaching of vocabulary: A perspective. Jurnal Kata: Penelitian Tentang Ilmu Bahasa Dan Sastra, 1(2), 182-191.

Travis, J., \& Geiger, M. (2010). The effectiveness of the Picture Exchange Communication System (PECS) for children with autism spectrum disorder (ASD): A South African pilot study. Child Language Teaching and Therapy, 26(1), 39-59. DOI: $10.1177 / 0265659009349971$

Tiley, C., \& Kyriakopoulos, M. (2021). The prevalence of autism spectrum traits and autism spectrum disorders in children and adolescents with obsessive compulsive disorder: a systematic review. BJPsych Open, 7(S1), S56-S56. doi: 10.1192/bjo.2021.195

Yunus, F. W., Bissett, M., Penkala, S., Kadar, M., \& Liu, K. P. (2019). Self-Regulated Learning versus Activity-based Intervention to Reduce Behavioral Problems and Enhance Schoolrelated Function for Children with Autism Spectrum Disorders: A Randomized Control Trial. Research Square. Preprint. Version 1, 1-14. https://doi.org/10.21203/rs.2.11561/v1

Zuparova, S., Shegay, A., \& Orazova, F. (2020). Approaches to Learning English as the Source of All. European Journal of Research and Reflection in Educational Sciences, 8(6), 102107. 